\title{
Zdrav življenjski slog starih ljudi
}

\begin{abstract}
Izziv dolgožive družbe je, kako zagotoviti takšno podporo in pomoč, da se bomo lahko starali čim bolj zdravo in samostojno. Včlanku je prikazano, kaj so pomembni dejavniki kakovostnega staranja, še posebej pomen zdravega življenjskega sloga in znotraj tega aktivnosti gibanja in socialnih omrežij. Kvantitativna raziskava na neslučajnostnem priložnostnem vzorcu 209 ljudi, starejših od 65 let, izvedena s pomočjo ankete, je pokazala, da skoraj vsi anketirani stari ljudje ocenjujejo, da lahko vzdržujejo zdrav življenjski slog in da na njihovo življenje najbolj vpliva starost. Z gibanjem se jih vsaj trikrat na teden ukvarja skoraj polovica, a pogostejša aktivnost ni povezana z boljšim zdravstvenim stanjem. Več kot polovica ima na voljo tri ali več oseb, na katere se lahko obrnejo po pomoč, in ti tudi bolje ocenjujejo svoje zdravje. Ni pa samoocena zdravja povezana s pogostostjo druženja. Bolj izobraženi pogosteje menijo, da lahko s svojim načinom življenja vplivajo nazdravje. Seznanjenostzaktivnostmi in dogodkizazdravživljenjskislog pajeslaba. Zaspodbujanjezdravega življenjskega sloga so potrebni ukrepi na vseh ravneh - mikro, mezo in makro.
\end{abstract}

Ključne besede: demografske spremembe, demografsko staranje, zdravje, kakovostno staranje.

Katarina Cesar, mag. soc. del. (UN), je magistrirala na Fakulteti za socialno delo na področju socialnega dela s starimi ljudmi. Kontakt: katarina.cesar@nijz.si.

Doc. dr. Branko Gabrovec je vodja koordinacije območnih enot Nacionalnega inštituta za javno zdravje in habilitiran visokošolski učiteljza področje javnegazdravstva na Fakultetiza zdravstvene vede Univerze v Mariboru. Kontakt: branko.gabrovec@nijz.si.

Doc. dr. Liljana Rihter je zaposlena kot visokošolska učiteljica in raziskovalka na Fakulteti za socialno delo Univerze v Ljubljani. Kontakt: liljana.rihter@fsd.uni-lj.si.

\section{Active aging from the perspective of older people}

The challenge of a long-lived society is how to provide such support and help that we will be able to age as healthily and independently as possible. The article shows what are the important factors of quality aging, with special emphasis on the importance of a healthy lifestyle and within this, sports and recreational activity and social networks. A quantitative study on a non-randomized convenience sample of 209 people over the age of 65 conducted by a survey found that almost all surveyed older people estimate that they can maintain a healthy lifestyle and that their lives are most affected by age. Almost half of them are engaged in exercise three times a week or more, but more frequent activity is not associated with better health. More than half have three or more people available to whom they can turn for help, and they also better assess their health. However, self-assessment of health is not related to the frequency of socializing. The more educated are more likely to believe that they can influence their health through their lifestyle. Familiarity with activities and events for a healthy lifestyle, however, is weak. To promote a healthy lifestyle, measures are needed at all levels - micro, mezzo and macro.

Key words: demographic change, population aging, health, quality aging.

Katarina Cesar has a Master's degree in Social work. Topic of her Master's degree: social work with older people. Contact: katarina.cesar@nijz.si.

Assistant Professor Branko Gabrovec is the Head of coordination of regional units of the National Institute of Public Health and a university teacher in the field of Public Health at the Faculty of Health Sciences, University of Maribor. Contact: branko.gabrovec@nijz.si.

Assistant Professor Liljana Rihter is employed as a university teacher and researcher at the Faculty of Social Work, University of Ljubljana. Contact: liljana.rihter@fsd.uni-lj.si. 


\section{Uvod}

Podaljševanje življenjske dobe, zmanjšanje smrtnosti in stopnje rodnosti so dejavniki, ki vplivajo na starostno strukturo prebivalstva oziroma na večanje deleža starih ljudi. Temu pravimo demografsko staranje oziroma demografske spremembe (Filipovič Hrast, 2018), družba postaja bolj dolgoživa. Evropske družbe veljajo za najhitreje starajoče se družbe, med njimi je Slovenija v samem vrhu (Voljč, 2017). Vedno daljša življenjska doba ljudi je posledica napredka in razvoja v družbi, gospodarstvu (Urad za makroekonomske analize in razvoj, b.d.), zdravstvu in kakovosti življenja (Filipovič Hrast in Hlebec, 2015).

Napredek na raznih področjih omogoča daljšo življenjsko dobo, to pa ne pomeni nujno, da je daljše življenje tudi zdravo in kakovostno (Gabrovec in Eržen, 2016). Ob tem so družbena okolja nepripravljena na zagotavljanje pomoči ljudem, ki zaradi starosti določenih opravil ne morejo več opravljati sami (Toth, 2009). To bo še večji izziv, ko bo zaradi dolgožive družbe vedno manj sposobnih za izvajanje neformalne oskrbe, hkrati pa se bo povečevalo število odvisnih od pomoči drugih (Dolgotrajna oskrba v Evropski uniji, 2008).

Starost zaznamuje zmanjševanje telesnih in duševnih zmožnosti. Poveča se možnost, da oseba zboli, oslabi, se poškoduje, postane osamljena in torej izgubi neodvisnost, avtonomijo, mobilnost, socialno interakcijo in vključenost v družbeno življenje (Gabrovec in Jelenc, 2015). Nemalokrat posameznika s slabim zdravstvenim stanjem spremlja trpljenje v obliki bolečin (Bond, 2004). Stari ljudje nato postanejo odvisni od drugih, začutijo potrebo po bivanju v instituciji ali celo prezgodaj umrejo (Gabrovec in Jelenc, 2015).

Izziv družbe ob pospešenem staranju prebivalstva je, kako zagotoviti tako podporo in pomoč, da se bomo lahko starali zdravo in samostojno, imeli kakovostno življenje in zmanjšali pritisk na zdravstvene ter socialne sisteme. Zato želimo s člankom pokazati, da lahko ob ustrezni sistemski podpori vsak posameznik pomembno vpliva na dejavnike staranja. Pomembno je spodbuditi skrb za zdravo staranje (Zveza društev upokojencev Slovenije, 2013), saj ne glede na opozorila, da zdrav življenjski slog vpliva na zmanjšanje ali preprečevanje obolelosti, in ne glede na priporočila za udejanjanje zdravega življenjskega sloga, mnogi napotkov ne vzamejo resno (Povše, 2010). Pri načrtovanju ukrepov je potreben miselni in akcijski premik od pojmovanja starih ljudi kot pasivnih uporabnikov, ki imajo velike potrebe, k poudarjanju njihovih pravic in pomena vključenosti (Domanjko in Pahor, 2011). Okrepiti želimo ozaveščenost in zanimanje za preventivno skrb za zdravje in s tem za svojo prihodnost. Pri tem ima socialno delo pomembno vlogo, saj razvija znanja tako za razumevanje širšega družbenega konteksta (makroraven), za delovanje v skupnostih (mezoraven) kot tudi za neposredno pomoč in podporo starim ljudem (mikroraven), pri tem pa izhaja iz potreb starih ljudi (Mali, 2013).

V članku se osredotočamo najprej na konceptualizacijo zdravega življenjskega sloga; na ovire, ki ljudem preprečujejo, da bi skrbeli za svoje zdravje, in na spodbude, ki bi bile potrebne na različnih ravneh, da bi stari ljudje lažje skrbeli za zdrav življenjski slog. Pri tem ima lahko pomembno vlogo socialno delo. Nato prikažemo rezultate raziskave, s katero smo želeli ugotoviti, kako na skrb za 
svoje zdravje gledajo stari ljudje, kateri so dejavniki, ki najbolj vplivajo na zdravje, ali si zdrav življenjski slog lahko privoščijo, kakšen življenjski slog imajo, ali je njihovo okolje naklonjeno zdravemu življenjskemu slogu, kakšne so njihove navade $v$ zvezi z gibalnimi aktivnostmi, kakšne so značilnosti njihovih socialnih mrež in kako se posamezni dejavniki, ki so povezani z možnostjo zagotavljanja zdravega življenjskega sloga, povezujejo z nekaterimi demografskimi dejavniki, kot sta izobrazba in starost. Na podlagi teh rezultatov je možen razmislek, kaj so potrebne spremembe in prizadevanja na različnih ravneh (mikro, makro in mezo), ki bi podprle zdrav življenjski slog starih ljudi.

\section{Zdrav življenjski slog in socialno delo}

Zdravje je celovit in dinamičen proces, od katerega je odvisno posameznikovo prilagajanje na delovanje zunanjega okolja, izvajanje biološke, socialne in poklicne funkcije, zmožnost onemogočati bolezen, onemoglost in prehitro smrt (Zdrav življenjski slog - trajnostni razvoj, b.d.). »Zdravje je stanje popolnega telesnega, duševnega in socialnega blagostanja in ne le odsotnost bolezni ali nemoči« (World Health Organization, b.d.). Iz tega izhaja, da je posameznikovo zdravstveno stanje idealno takrat, ko je popolnoma funkcionalno neodvisen od pomoči drugih. Nekateri podatki kažejo na to, da je v tem primeru $5 \%$ starih ljudi nezmožnih, $20 \%$ ranljivih in $75 \%$ neodvisnih (Gabrijelčič Blenkuš in Stanojević Jerković, 2010).

Vsak posameznik si v življenju določa svoja pravila, razvija navade, izvaja različne aktivnosti, pripisuje istim stvarem drugačen pomen oziroma živi življenje na svoj način, ki mu pravimo življenjski slog (Novak, 2010).Zdrav življenjski slog je eden izmed pomembnejših dejavnikov, ki vplivajo na posameznikovo zdravje, izboljšuje kakovost življenja, povečuje neodvisnost od pomoči drugih in podaljšuje aktivnosti ljudi v starosti (Zveza društev upokojencev Slovenije, 2013). Za zdrav življenjski slog so značilna dejanja, ki imajo pozitiven oziroma neškodljiv vpliv na zdravje ob hkratnem izogibanju čim več škodljivim navadam. Med ta dejanja uvrščamo: skrb za telesno kondicijo s pomočjo gibalnih dejavnosti, za dovolj spanca, za uravnoteženo prehrano in ustrezno količino hrane, za osebno higieno, odrekanje uživanju alkoholnih pijač, kajenju tobačnih izdelkov idr. (Petrovec, Bizjak, Rednak Robič, Kopasić in Kramar, b.d). Pomemben je tudi vpliv načina razmišljanja in spoprijemanja s stresom (Lesnik, 2016).

Tveganje v starosti najpogosteje povzročajo spremembe v telesnem in duševnem zdravju, slabšanje finančnega položaja, manjšanje socialnih omrežij in s tem izguba socialne opore, vse to pa vpliva na zmanjševanje samostojnosti in kakovosti življenja (Domanjko in Pahor, 2011). Kavčič (2011, str. 180) opiše štiri večje kategorije najpogostejših tveganj v starosti:

1.) zdravstvena tveganja (padci, nesreče, poškodbe, bolezni, neustrezno jemanje zdravil, podhladitev, gibalne težave, pozabljivost, preobremenitev, podhranjenost, dehidracija);

2.) finančna tveganja (prenizke pokojnine, večanje finančne obremenitve zaradi zdravstvenega stanja, nezmožnost nadzorovanja in upravljanja svojih financ, kreditna nesposobnost); 
3.) socialna tveganja (konflikti, nasilje, izguba partnerja, razpad omrežja, osamljenost, selitev v novo okolje, nepripravljenost na starost);

4.) strukturna tveganja (pomanjkljiv javni promet, pomanjkljiv zdravstveni sistem, nedostopnost storitev, družbene in tehnološke spremembe).

V članku opisujemo dva dejavnika zdravega življenjskega sloga - izvajanje gibalnih dejavnosti in socialna omrežja - in sicer zaradi velikega vpliva na kakovost življenja v starosti in njune medsebojne povezanosti.

Statistični podatki kažejo, da ima na zdravstveno stanje posameznika od vseh dejavnikov največji vpliv življenjski slog. Delež njegovega vpliva je kar 40-odstoten, 30-odstotnega imajo dedni in biološki dejavniki, 20-odstotnega naravno, ekonomsko, bivalno in družbeno okolje, 10-odstotnega pa javne zdravstvene službe (Česen, 2006). Gibanje v starosti varovalno vpliva na ohranjanje telesih zmožnosti in spretnosti (psihofizičnih in funkcionalnih), ki jih človek potrebuje za opravljanje vsakodnevnih opravil in dejavnosti (Drev, 2010). Redno in zadostno izvajanje gibalnih dejavnosti pripomore k preprečitvi oziroma omilitvi padcev in poškodb pri padcih, k preprečevanju oziroma odpravljanju težav pri gibanju in k preprečevanju popolne nemobilnosti (Kavčič, 2011, str. 181-187). Z redno telesno dejavnostjo varujemo telo pred večjim delom nenalezljivih kroničnih bolezni (Drev, 2010). Posledice nezadostnega gibanja so lahko degenerativno obolenje, slabitev temeljnih življenjskih funkcij in prezgodnja smrt (Pečjak, 1998). Ne dovolj aktivni imajo 20-30 \% več možnosti za zgodnejšo smrt kot tisti, ki so dovolj dejavni (World Health Organization, 2018).

Telesno zdravje pomembno vpliva tudi na duševno počutje starih ljudi. Gibalno aktivni veliko duševnih obremenitev prenesejo lažje in se nanje primerno odzovejo (Accetto, 1987). Vpliv telesne aktivnosti se kaže v splošnem počutju, samospoštovanju in samozavesti, v odpornejšem imunskem sistemu in kakovostnejšem spancu (Povše, 2010).

Pomembno pa vpliva tudi na socialno področje. S telesno dejavnostjo se mnogi aktivneje vključujejo v družbo in vzpostavljajo socialne stike. Na dolgi rok so (stari) ljudje lahko tako manj osamljeni, pridobijo stabilne in aktivne vloge v družbi in sklepajo nova prijateljstva (Gabrijelčič Blenkuš in Stanojević Jerković, 2010). Socialne vezi imajo pomemben vpliv na to, kako potekajo in se izidejo posameznikovi življenjski prehodi in krize (Filipovič Hrast in Hlebec, 2015). Posameznik se z drugimi posamezniki povezuje na različne načine, navsezadnje je to ena izmed ključnih človeških potreb in lastnosti.

Medčloveška razmerja in odnosi so za človeka v resnici kot mreža, pojem socialna mreža pa se tako nanaša na človekovo vseživljenjsko vpetost v medčloveške povezave (Inštitut Antona Trstenjaka, n.d.). Socialna mreža je potencial možnih virov moči in rešitev. To je še posebej pomembno pri delu s starimi ljudmi, saj je zanje pomoč drugega oziroma pomoč iz njihovega socialnega okolja pogosto nujna. S tem mislimo tako na formalno pomoč (strokovnjaki, institucije, organizacije) kot tudi na neformalno (družina, prijatelji, svojci, znanci) (Mali, 2013). Večja in kakovostnejša kot je socialna mreža posameznika, bolje in lažje obvladuje življenje. To pomeni, da imajo socialne mreže pomemben vpliv tudi na duševno zdravje (Tacol in Goličnik, 2014). 
Kot drugi pomembnejši element zdravega načina življenja torej predstavljamo socialne mreže, saj so lahko varovalni dejavnik (Dragoš, 2000). Še posebej pomembni so vzajemni in trajni odnosi. Socialna opora, ki jo prejmemo iz svojega socialnega omrežja, je lahko čustvena, materialna in informacijska. Tisti, ki imajo zadostno socialno oporo, so tudi bolj zaščiteni pred stresom. Socialna opora ljudem zagotavlja občutek ljubljenosti, sprejetosti in spoštovanja. Za stare ljudi so pomembna predvsem neformalna omrežja, saj so izjemno pomembna pri zagotavljanju pomoči, ki jo stari ljudje pogosto nujno potrebujejo, a seveda le v primeru, če so ti odnosi kakovostni in jih ne obremenjujejo, niso izvor stresa in konfliktnih situacij (Filipovič Hrast in Hlebec, 2015).

Zdrav življenjski slog je dinamičen proces in je odvisen od vsestranskega pristopa k vsem vidikom naših dejavnosti - telesni, čustveni, razumski, duhovni in socialni (Berčič in Sila, 2007; Povše, 2010). Odgovornosti za skrb za zdrav življenjski slog ne smemo prelagati zgolj na posameznika, saj je zdrav življenjski slog odvisen od različnih socialno-ekonomskih dejavnikov. Slabša izobrazba, nižji dohodek, slabše bivalne razmere, nižji družbeni sloj, predsodki, ki se navezujejo na stare ljudi, ipd., po navadi negativno vplivajo na posameznikov življenjski slog. Odgovornost družbe je, da ustvari čim več možnosti, da bi lahko bilo naše življenje v tretjem življenjskem obdobju kakovostno oziroma da bodo zagotovljene okoliščine za dostojno življenje in osebno rast (Gabrovec in Eržen, 2016).

Rafaelič in Nagode (2012) ugotavljata, da so storitve, ki se izvajajo v Sloveniji na področju oskrbe ljudi v tretjem življenjskem obdobju oziroma predvsem tistih, ki potrebujejo dolgotrajno oskrbo, zagotovljene v povezavi: $\mathrm{z}$ institucionalnim varstvom (dom za stare ljudi, varstveno-delovni center, socialnovarstveni zavod); s skupnostno oskrbo oziroma oskrbo na domu; z vmesnimi strukturami oziroma dnevnimi oblikami varstva (dnevni center, varovanje na daljavo, družinski pomočnik); z denarnimi prejemki (dodatek za pomoč in postrežbo). Storitve dolgotrajne oskrbe so tako socialno- in zdravstvenovarstvene (Nagode, Zver, Marn, Jacović in Dominkuš, 2014).

Socialne delavke morajo pozornost preusmeriti od institucij k posameznikom. Pomembno je, da spremljajo in preučujejo spreminjajoče se potrebe starih ljudi in se nanje aktivno odzivajo (Mali in Leskošek, 2015). Socialna delavka je pogosto posrednica med različnimi službami in viri pomoči. Starim ljudem in njihovim svojcem pomaga pridobiti podporo pri različnih službah, hkrati pa je v vlogi koordinatorke storitev, ki jih je star človek deležen. Ker spoznava potrebe starih ljudi, lahko pripomore k razvoju storitvenih dejavnosti (Mali, 2008). Socialno delo odlikuje sposobnost za pozitivno vrednotenje starosti. Stare ljudi z njihovimi potrebami razume holistično, jih dojema kot partnerje in s tem poudarja njihove pravice in možnost izbire vrste pomoči (Mali, 2018a). Svojih uporabnikov ne obravnava kot pasivnih prejemnikov pomoči, ampak kot sooblikovalce in soustvarjalce življenja, ki je tudi v starosti lahko kakovostno (Mali, 2012).

Za zagotavljanje kakovosti življenja pa je pomemben tudi zdrav življenjski slog (Petrovec, Bizjak, Rednak Robič, Kopasić in Kramar, b.d.). Socialno delo 
prepoznava raznovrstnost življenjskega sveta starih ljudi, njihovega vsakdana in težav, ki so posledica specifike življenja v starosti ter družbenega obravnavanja starosti. V središču zanimanja je star človek s svojimi sposobnostmi in zmožnostmi. Zato pomoč in podpora temeljita na osebnih izkušnjah, iz katerih človek jemlje moč, ki jo potrebuje za premagovanje težavne sedanjosti (Mali, 2013). V tem pogledu lahko pomaga odkrivati okoliščine, ki stare ljudi na eni strani ovirajo pri izvajanju gibalnih aktivnosti oziroma pomenijo pomanjkanje virov v socialnih omrežjih, na drugi strani pa tudi tiste, ki pomenijo spodbudo in vire moči ter lahko pomembno pripomorejo k spodbujanju zdravega življenjskega sloga.

\section{Problem in metodologija raziskave}

Namen raziskave je ugotoviti, kako na skrb za zdravje gledajo stari ljudje, kateri dejavniki po njihovem mnenju najbolj vplivajo na zdravje, ali si zdrav življenjski slog lahko privoščijo, kakšen je njihov življenjski slog, ali je njihovo okolje naklonjeno zdravemu življenjskemu slogu, kakšne navade v zvezi z gibalnimi aktivnostmi imajo in kakšne so značilnosti socialnih mrež. Rezultati raziskave lahko pripomorejo:

- k sistematičnim ukrepom za preprečevanje zdravstvenih stanj, ki povzročajo odvisnost posameznika od drugih oseb;

- $\mathrm{k}$ ustreznejšemu, na podlagi interesa ljudi utemeljenem promoviranju zdravega življenja;

- k oblikovanju aktivnosti in podpornih služb, ki bi skrbele za učinkovitejšo preventivno skrb za zdravje;

- k oblikovanju zakona o dolgotrajni oskrbi, ki bi posebno skrb namenil temu, da bi s pomočjo preventivne skrbi za zdravje zmanjšali število posameznikov, ki bi storitve dolgotrajne oskrbe sploh potrebovali.

Izhajali smo iz petih hipotez:

1. Anketirani, ki imajo več oseb, na katere se lahko obrnejo po pomoč, bolje ocenjujejo svoje zdravje kot tisti, ki imajo manj takih oseb.

2. Anketirani, ki imajo končano vsaj višjo ali visoko šolo, v večji meri menijo, da s svojim načinom življenja lahko vplivajo na svoje zdravstveno stanje, kot tisti, ki imajo končano srednjo šolo ali nižjo izobrazbo.

3. Anketirani, ki gibalne aktivnosti izvajajo vsaj trikrat na teden, imajo manj bolezni oziroma zdravstvenih težav kot tisti, ki gibalno aktivnost izvajajo največ dvakrat na teden.

4. Anketirani, ki se vsaj enkrat na teden družijo z drugimi osebami, ocenjujejo svoje zdravje bolje kot tisti, ki se družijo manj pogosto.

5. Starejši kot so anketirani, manj so seznanjeni z aktivnostmi in dogodki, ki se navezujejo na zdrav življenjski slog.

Izvedli smo kvantitativno raziskavo ${ }^{1}$ in s pomočjo strukturiranega anketnega vprašalnika zbirali novo neposredno izkustveno gradivo. Na podlagi

1 Raziskava je bila izvedena $v$ okviru magistrskega dela prve avtorice tega članka. V članku predstavljamo izsek ugotovitev, ki se nanašajo na zdrav življenjski slog, izvajanje gibalnih aktivnosti in socialne mreže. 
tega gradiva smo količinsko opredelili osnovne značilnosti raziskovane teme (dejavniki, ki vplivajo na zdravje, ne/obstoj zdravega življenjskega sloga, značilnosti izvajanja gibalnih dejavnosti, značilnosti socialnih mrež ipd.) in ugotovili obstoj zveze med dvema ali več pojavi. Strukturiran anketni vprašalnik je vseboval 27 vprašanj, razdeljenih v pet sklopov. V nekaterih primerih smo uporabili lestvico definiranih kategorij. Na podlagi te lestvice so anketirani z oceno od 1 do 5 ocenili strinjanje s trditvijo. $V$ drugih primerih smo postavili vprašanja, ki so vsebovala vnaprej oblikovane možnosti odgovorov. Za namen članka smo analizirali te spremenljivke: finančno stanje, izobrazba, razpoložljiva opora v socialni mreži, mnenje o možnosti vpliva na zdravje, obstoj bolezni/zdravstvenih težav, pogostost, način in trajanje izvajanja gibalne aktivnosti, ne/obstoj zdravega načina življenja, pogostost druženja z drugimi osebami, seznanjenost z dogajanjem v bližini.

Populacija raziskovanja so bili ljudje, ki so bili v obdobju raziskovanja (15. 4. 2019 do 15. 1. 2020) stari vsaj 65 let in so bivali v Sloveniji. Anketirani so bili izbrani na podlagi neslučajnostnega, priložnostnega vzorčenja po metodi snežne kepe. V obdobju devetih mesecev smo razdelili 262 anketnih vprašalnikov, izpolnjenih pa smo dobili 209. Anketirani so razpršeni po različnih območjih Slovenije, vključeni so tisti, ki bivajo na podeželju, v mestih, obrobjih mest, $v$ institucionalnem varstvu in domačem okolju.

Podatke smo analizirali s statističnim programom IBM SPSS V21. V analizi smo zajeli: deskriptivno metodo, korelacijsko analizo, $\chi 2$ test , Kolmogorov-Smirnov test in Mann-Whitney U test. Vprašalnik se je pokazal za notranje zanesljivega (Cenčič, 2009) - Cronbach's alpha: 0.759. Statistično pomembnost smo opredelili na $\mathrm{p}<0.05$.

\section{Rezultati}

V raziskavo je bilo vključenih 63,4 \% žensk in 36,6 \% moških. Razdeljeni so bili v starostne skupine: $65-74$ let (54,6\% anketiranih), 75-81 let (29,9\%), 82-89 let $(12,6 \%)$ in 90 ali več let $(2,9 \%$ anketiranih). Od tega jih je $59,6 \%$ končalo največ srednjo šolo, 24,5 \% osnovno šolo ali manj, 11,5 \% višjo šolo, 4,4 \% pa vsaj visoko šolo. S sedanjimi prihodki se je brez težav preživljalo $36,2 \%$ anketiranih, komaj je še shajalo 47,3 \%, težko pa se je preživljalo $16,5 \%$ anketiranih. Glede na podatke Statističnega urada Republike Slovenije (b.d.b) za leto 2019 smo v vzorec zajeli anketirane, ki so po stopnji izobrazbe primerljivi s stopnjo izobrazbe splošne populacije starih ljudi v Sloveniji. Se pa nekatere značilnosti vzorca po določenih demografskih značilnostih precej razlikujejo od značilnosti populacije. Pokazalo se je, da je v primerjavi med anketiranimi in gospodinjstvi v Sloveniji na splošno (Statistični urad Republike Slovenije, b.d.a) za 17,9 \% več anketiranih takih, ki se s sedanjimi prihodki preživljajo brez težav, in manj tistih, ki se preživljajo s težavo. Tako smo v vzorec dobili več starih ljudi z boljšim finančnim položajem.

Kar 88,1 \% anketiranih meni, da s svojim načinom življenja lahko vplivajo na svoje zdravje, 11,9 \% pa jih je nasprotnega mnenja. Zdravo živi 90,2 \% anketiranih. Vsaj štirim dejavnikom, ki škodljivo vplivajo na način življenja 
(npr. uživanje alkoholnih pijač, kajenje, čezmerna telesna teža), se izogiba kar $59 \%$ anketiranih.

Anketirani so menili, da na njihovo zdravje najbolj vplivajo: starost $(63,6$ $\%)$, stres (42,2\%), dedovanje bolezni $(30,1 \%)$, prehrana $(26,7 \%)$, debelost $(23,3 \%)$, finančni dohodek (17\%), gibanje $(15,5 \%)$, kajenje $(13,6 \%)$, uživanje alkoholnih pijač $(12,6 \%)$, nezadovoljstvo z življenjem $(8,7 \%)$, neuspešnost v življenju $(2,9 \%)$ in stiki z drugimi ljudmi $(2,4 \%)$. V povprečju pa ima vsak izmed anketiranih 4,23 zdravstvenih težav (od 22 bolezni/zdravstvenih težav, ki so bile navedene v vprašalniku).

Graf 1: Ocena anketiranih o vplivu nekaterih dejavnikov na njihovo zdravje.

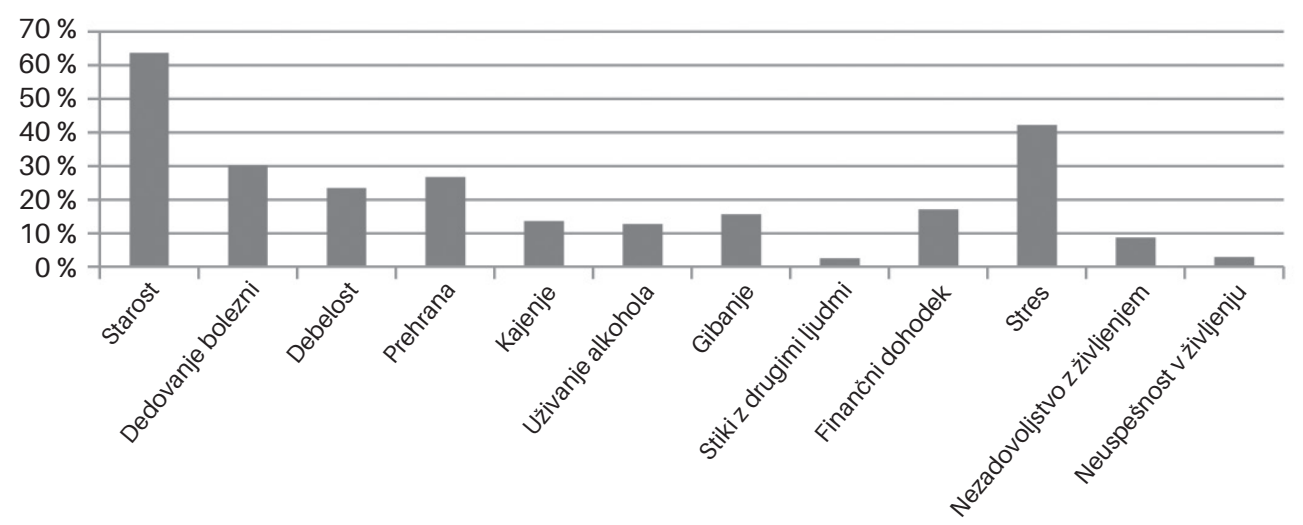

Vsaj trikrat na teden se z gibalno dejavnostjo, ki poveča srčni utrip, povzroči občutek toplote in blago zadihanost, ukvarja kar 45,6 \% anketiranih, 28,5 \% se jih z njo ukvarja dvakrat na teden, $25,9 \%$ pa največ enkrat na teden. Pri tem jih gibalno aktivnost 45,3 \% izvaja vsaj 30 minut, 36,7 \% 10-30 minut, drugi pa manj. Anketirani si gibalne dejavnosti najpogosteje organizirajo samostojno $(67,7 \%)$, organizirano ali skupinsko vodeno $13,4 \%, 9,8 \%$ jih gibalne aktivnosti ne izvaja, 9,1\% pa jo izvaja v družbi prijateljev.

Ko so anketirani odgovarjali na vprašanje: »Na koliko znanih oseb se lahko kadarkoli obrnete po pomoč? «, se je pokazalo, da jih ima 58,7 \% na voljo tri ali več oseb, 38,9 \% eno do dve takšni osebi, $2,4 \%$ anketiranih pa nima nikogar.

Graf 2: Število oseb, ki so anketiranim vsak hip na voljo za pomoč.

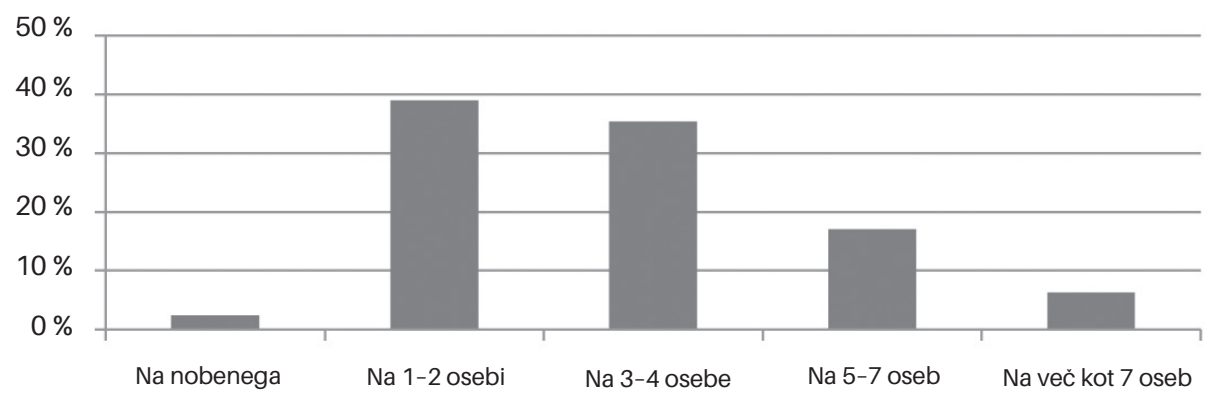


Med anketiranimi se je 39,6 \% vsak dan družilo z drugimi osebami, 38,2 $\%$ nekajkrat na teden, $17,4 \%$ vsaj enkrat na teden, $4,8 \%$ pa manj kot enkrat na teden.

Anketirani so na lestvici od ena do pet $(1=$ sploh se ne strinjam, $2=$ ne strinjam se, 3 = delno se strinjam, $4=$ strinjam se, $5=$ popolnoma se strinjam) ocenili nekaj trditev, ki se nanašajo na možne ukrepe, ki bi lahko pripomogli k bolj zdravemu načinu življenja oziroma k večji aktivnosti ljudi. Najbolj (povprečna vrednost je 3,57) se strinjajo s trditvijo »za bolj zdravo življenje bi potreboval/a več finančnih sredstev oziroma več brezplačnih aktivnosti, povezanih s skrbjo za zdravje«. Nekoliko manj se strinjajo s trditvijo (povprečna vrednost je 3,37 ) »želim si bolj zdrave prehrane«. S povprečno oceno 3,27 so ocenili še trditev »seznanjen/a sem s predavanji, dogodki, aktivnostmi v povezavi z zdravim načinom življenja in so mi na voljo v moji bližini«. Se pa v povprečju (povprečna vrednost 2,26) ne strinjajo s trditvijo »želim si, da bi me tedensko obiskoval prostovoljec in mi pomagal pri oblikovanju zdravega življenjskega sloga, « in s trditvijo, ki se nanaša na željo, da bi jih nekdo spremljal na določeno aktivnost (povprečna vrednost 2,11).

Na podlagi preverjanja hipotez smo ugotovili, da anketirani, ki imajo več oseb, na katere se lahko obrnejo po pomoč, bolje ocenjujejo svoje zdravje kot tisti, ki imajo manj takih oseb (Pearsonov koeficient korelacije 0,64, p =0,019). Anketirani, ki imajo končano vsaj višjo šolo, pogosteje menijo, da z načinom življenja lahko vplivajo na svoje zdravstveno stanje, kot tisti, ki imajo končano največ srednjo šolo (Pearsonov hi kvadrat test znaša 5,127, p = 0,024). Sicer pa anketirani, ki gibalne aktivnosti izvajajo vsaj trikrat na teden, nimajo manj bolezni oziroma zdravstvenih težav kot tisti, ki gibalno aktivnost izvajajo manj pogosto. Razlike med skupinama niso bile statistično pomembne ( $p$ > $0,05)$. Ne velja, da starejši kot so anketirani, manj so seznanjeni z aktivnostmi in dogodki, ki se navezujejo na zdrav življenjski slog. Povezanost med spremenljivkama ni bila statistično značilna (Spearmanov koeficient korelacije $-0,63, p=0,383$ ). Kot kaže, samoocena zdravstvenega stanja ni odvisna od pogostosti druženja z drugimi osebami. Anketirani, ki se vsaj enkrat na teden družijo z drugimi osebami, sicer ocenjujejo svoje zdravje bolje kot tisti, ki se družijo manj. Izvedeni $\chi 2$ test pa prikazuje, da znaša vrednost Pearsonovega hi kvadrat testa 2,695, vrednost signifikance pa 0,610 ( $p>0,05)$. Povezanost med spremenljivkama ni bila statistično značilna.

\section{Razprava in sklepi}

Pristop, ki ga lahko označimo kot proaktivno življenje v starosti, se osredotoča na pripravo na negativne spremembe, $\mathrm{s}$ katerimi se srečamo $\mathrm{v}$ času tega življenjskega obdobja. S tem ne trdimo, da negativne vplive staranja lahko v celoti obidemo, lahko pa zmanjšamo negativne rezultate dejavnikov, ki povzročajo stres, okrepimo razpoložljive vire, ki pomagajo pri spoprijemanju s težavami, in odložimo izključenost iz družbe (Ouwehand, De Ridder in Bensing, 2007). K proaktivnim strategijam prištevamo zdrave življenjske navade (Kahana, Lawrence, Kahana, Kercher, Wisniewski in Stoller, 2002). 
V naši raziskavi se je pokazalo, da anketirani najpogosteje $(63,6$ \%) kot vzrok za njihove zdravstvene težave navajajo svojo starost. Domnevamo, da je to lahko znamenje pasivnosti, nevednosti, vdanosti $v$ usodo, miselnosti, da težave sodijo k starosti in jih ni mogoče preprečiti. A kljub temu večina anketiranih $(88,1 \%)$ meni, da s svojimi dejanji lahko vplivajo na svoje zdravje.

Vendar ne gre odgovornosti za skrb za zdravje pripisati zgolj ljudem samim. Eden od pomembnejših socialno-ekonomskih dejavnikov, ki vplivajo na posameznikovo zdravje, je finančno stanje (Povše, 2010). Od njega je namreč odvisno zadovoljevanje osnovnih življenjskih potreb (dostopnost stanovanja, kakovostna hrana, obleka in obutev ter zdravstvene storitve). V primeru slabšega finančnega stanja se posameznik ne more enakovredno vključevati v družbeno in socialno okolje, to pa se pozna na psihološkem stanju (občutek nesposobnosti, nespoštovanja, izključenosti, slabe samopodobe in nesamozavestnosti). Poleg tega podatki kažejo, da so tisti, ki so nižje izobraženi, velikokrat slabše ozaveščeni o zdravem načinu življenja in njegovem pomenu, to pa je mogoče opaziti na njihovem zdravstvenem stanju (Povše, 2010). Rezultati naše raziskave to potrjujejo. Anketirani, ki imajo končano vsaj višjo šolo, pogosteje menijo, da s svojim načinom življenja lahko vplivajo na zdravstveno stanje, kot tisti, ki imajo končano največ srednjo šolo. Zato je v družbi treba zagotoviti razmere, v katerih se bodo lahko tudi tisti z nižjimi dohodki in z nižjo stopnjo izobrazbe vključevali v dejavnosti, ki podpirajo zdrav življenjski slog.

Glede na raziskave v preteklosti je v Sloveniji med tistimi, ki so stari vsaj 65 let, približno 60 \% takšnih, ki so telesno nedejavni (Drev, 2010). Do skoraj enake ugotovitve (59 \% športno neaktivnih) sta prišla Karpljuk in Videmšek (2010). Podobni so rezultati raziskave Gabrijelčič Blenkuš in Stanojević Jerković (2010): $64 \%$ anketiranih športne aktivnosti ne izvaja oziroma so nedejavni. $V$ naši raziskavi je bilo nedejavnih oziroma dejavnih manj kot enkrat na teden $25,9 \%$ anketiranih. To lahko pomeni, da so ljudje na splošno postali aktivnejši, možno pa je, da smo v vzorcu po naključju zajeli večino tistih, ki so redno aktivni, oziroma najverjetneje na rezultate vpliva tudi to, da je največ anketiranih uvrščenih med mlajše stare ljudi in so ti verjetno na splošno aktivnejši. Lahko, da smo v vprašalniku »gibalno aktivnost« premalo natančno definirali in se je zato več ljudi uvrstilo med aktivne kot v kakšni drugi raziskavi, $v$ kateri so bile gibalne dejavnosti natančno določene. Poleg tega je bilo $v$ našo raziskavo vključenih tudi več tistih, ki živijo v domovih za stare ljudi, kjer vsak dan skrbijo za vodeno izvajanje gibalne aktivnosti uporabnikov.

Glede na to, kolikokrat na teden se anketirani ukvarjajo z gibalno aktivnostjo, so v vseh kategorijah pogostosti izvajanja gibalne aktivnosti (največ enkrat na teden, dvakrat na teden, tri- do petkrat na teden ali vsaj šestkrat na teden) razporejeni precej enakomerno (v vsako kategorijo se je uvrstilo več kot $20 \%$ anketiranih). Ker so anketirani v naši raziskavi precej aktivni, bi bilo zanimivo vedeti, kaj jih pri tem motivira, in to upoštevati pri sprejemanju ukrepov in promocije na področju gibanja, saj je glede na preostale raziskave, ki kažejo očitno pomanjkanje izvajanja gibalnih aktivnosti med starimi ljudmi, to potrebno. 
Poznavanje načina življenja ljudi je za socialno delo pomembno, saj pridobiva gradivo za konkretne akcije iz uporabnikovih življenjskih zgodb, poročil in opisov (Mali in Ovčar, 2010). Če se z uporabniki ne pogovarjamo, z njimi ne moremo sodelovati, soustvarjati in torej izvesti ukrepov, s katerimi bi izboljšali njihovo življenjsko situacijo (Mali in Žitek, 2016, str. 239). Bolj kot bomo vključevali stare ljudi v socialno delo in bolj kot bomo poskušali zadovoljiti njihove potrebe, bolj se bodo metode in spretnosti socialnega dela razvijale v smeri zadovoljevanja dejanskih potreb starih ljudi (Mali, 2018b).

Leta 2010 je bilo po svetu približno $23 \%$ odraslih (starih vsaj 18 let) premalo aktivnih. Kar $81 \%$ pa je bilo premalo aktivnih mladostnikov, starih od 11 do 17 let (World Health organization, 2018). H gibanju je težko motivirati tiste, ki tega niso navajeni že iz otroštva, ki s športom nimajo dobrih izkušenj, ki zaradi pomanjkanja kondicije pri začenjanju izvajanja gibalne aktivnosti zaradi obremenitve trpijo in jim to vzame voljo do nadaljevanja, tiste, ki niso dovolj samodisciplinirani, ipd. Velikanski vpliv na motivacijo lahko imajo pozitivne spremembe, ki bi bile lahko posledica zadostnega gibanja. Če posamezniki pozitivnih rezultatov ne vidijo dovolj hitro, izgubijo motivacijo za nadaljnje pozitivno ravnanje. Velikokrat pa v družbi še vedno lahko opazimo predsodke, ki se navezujejo na gibanje starejših, češ da so za to prestari oziroma da zanje to ni primerno.

Svetovna zdravstvena organizacija (World Health Organization, 2018) za ljudi, stare vsaj 65 let, priporoča izvajanje zmerne telesne aktivnosti vsaj 150 minut na teden. Za to, da telesna dejavnost pozitivno vpliva na zdravje, jo je treba izvajati vsaj deset minut strnjeno. Kar $82 \%$ anketiranih je izvajalo gibalno aktivnost strnjeno vsaj 10 minut. Po merilih Svetovne zdravstvene organizacije (World Health Organization, 2018) se tako ni gibalo dovolj $18 \%$ anketiranih $\mathrm{v}$ naši anketi.

Glede na trditve različnih avtorjev (Drev, 2010; Vilčnik, b.d.; Pečjak, 1998; Povše, 2010), da z rednim izvajanjem gibalnih aktivnosti pomembno pripomoremo k telesnemu in duševnemu zdravju, da smo čim dlje in čim bolj funkcionalno zmožni, ter torej h kakovostnejšemu življenju, je presenetljivo, da smo morali ovreči hipotezo, da »imajo anketirani, ki gibalne aktivnosti izvajajo vsaj trikrat na teden, manj bolezni oziroma zdravstvenih težav kot tisti, ki gibalno aktivnost izvajajo največ dvakrat na teden«. Možna razlaga tega je, da so med anketiranimi prevladovale mlajše starejše osebe, ki še nimajo veliko zdravstvenih težav.

Večina anketiranih $(67,7 \%)$ v naši raziskavi se gibalne dejavnosti loteva samostojno, manj organizirano ali v družbi prijateljev. To se nam zdi zanimivo, saj glede na izkušnje vemo, da ljudi pogosto h gibalni aktivnosti motivira družba. Veliko ljudi se lažje odloči za gibanje, če vedo, da jih bo nekdo nekje pričakal, jih vodil in spodbujal. Poleg tega je z organiziranimi dejavnostmi posamezniku omogočena strokovno nadzorovana vadba, ki zagotavlja večjo varnost, vadba je redna in tudi zabavnejša. Razlog za slabo udeleževanje organiziranih gibalnih aktivnosti naših anketiranih bi lahko bil v tem, da se te aktivnosti izvajajo stran od kraja bivanja starih ljudi in so zaradi omejenih možnosti mobilnosti manj dostopne. Pri samostojnem izvajanju telesne dejavnosti se ni treba nikomur časovno in krajevno prilagajati ter je zato aktivnost lažje dostopna oziroma 
so ljudje za izvajanje neodvisni od drugih. Razlog za neudeleževanje organiziranih dejavnosti bi med mnogimi drugimi lahko bil v tem, da te dejavnosti premalo zadovoljujejo potrebe in želje starih ljudi. Obstaja tudi možnost, da si organiziranih dejavnosti, ki sicer ne veljajo za osnovno življenjsko potrebščino, stari ljudje težko privoščijo oziroma si jih sploh ne morejo privoščiti, saj je zanje večinoma treba plačevati drage članarine.

Glede na povprečje strinjanja s trditvijo »seznanjen/a sem s predavanji, dogodki, aktivnostmi v povezavi z zdravim načinom življenja in so mi na voljo v moji bližini«, bi lahko sklepali, da bi ljudje morali biti tudi bolje obveščeni (sicer je ocena strinjanja razmeroma visoka, a očitno veliko ljudi nima informacij o možnostih v njihovem okolju). Ker je vedno več informacij dostopnih na spletu (nekatere zgolj tam) in ker stari ljudje velikokrat še niso seznanjeni z novimi tehnologijami, smo predvidevali: starejši kot so anketirani, manj so seznanjeni z aktivnostmi in dogodki, ki se navezujejo na zdrav življenjski slog. Prav tako med starimi ljudmi pogosto ni izpolnjen prvi pogoj za izvajanje digitalnih aktivnosti - ustrezna opremljenost z napravami (računalnik, modem, internetni priključek, mobitel ipd.) (Ramovš, 2006).

Poleg tega starejši kot je človek, manjša je (po navadi) njegova socialna mreža oziroma socialna opora, ki je lahko čustvena, materialna in informacijska (Filipovič Hrast in Hlebec, 2015). Mi smo na podlagi pridobljenih podatkov hipotezo »starejši kot so anketirani, manj so seznanjeni $\mathrm{z}$ aktivnostmi in dogodki, ki se navezujejo na zdrav življenjski slog«, ovrgli. Zanimivo bi bilo vedeti, ali bi z večjo informiranostjo starih ljudi na način, ki jim je blizu (na primer po pošti), lahko pripomogli k večji udeležbi aktivnosti in dogodkov, ki se navezujejo na zdrav življenjski slog.

Rezultati naše raziskave kažejo, da le malo anketiranih nima nikogar, na kogar bi se lahko kadarkoli obrnili po pomoč. Prevladujejo tisti, ki imajo 1-2 osebi, in tisti, ki imajo 3-4 osebe. Anketirani imajo socialne stike z drugimi po večini vsak dan ali pa vsaj nekajkrat na teden. Zelo malo $(4,8 \%)$ je takih, ki jih ima stike z drugimi manj kot enkrat na teden. Glede na rezultate drugih raziskav je vidno, da socialne mreže vplivajo na zdravstveno stanje in smrtnost starih ljudi, kardiovaskularna obolenja, umrljivost zaradi rakavih obolenj in na raven funkcionalnih zmožnosti (Dragoš, 2000).

Tudi v naši raziskavi se je pokazalo, da imajo socialne mreže anketiranih vpliv na njihovo zdravje. Potrdili smo hipotezo: »Tisti anketirani, ki imajo več oseb, na katere se lahko obrnejo po pomoč, bolje ocenjujejo svoje zdravje kot tisti, ki imajo manj takih oseb. « Tisti z več socialnimi stiki imajo več možnosti, da bodo deležni podpore in pomoči (Selič, 1999). Ni pa splošnega pravila, ki bi določalo, kolikšno je zadostno število ljudi, ki jih posameznik v svojem omrežju potrebuje, da je srečen oziroma da ga ti zadovoljijo. To je odvisno od vsakega posameznika, od njegovega načina življenja, potreb in želja. Menimo, da je pomembnejša kakovost odnosov kot njihovo število in pogostost stikov.

Izhajali smo iz hipoteze, da anketirani, ki se vsaj enkrat na teden družijo z drugimi osebami, ocenjujejo svoje zdravje bolje kot tisti, ki se družijo manj, a smo jo pozneje na podlagi pridobljenih podatkov ovrgli. Iz tega sklepamo, da ni toliko 
pomembna pogostost stikov z ljudmi kot pa zavedanje, da imamo koga, na koga se lahko obrnemo po pomoč ali za druženje, če bi to potrebovali oziroma želeli.

Socialno delo je pomembno pri prepoznavanju stisk starih ljudi in pri iskanju odgovorov nanje, deluje pa na treh ravneh - mikro, mezo in makro (Mali, 2013). Glede na ugotovitve naše raziskave ugotavljamo, da bi na mikroravni bilo treba natančneje raziskati možnosti zagotavljanja zdravega načina življenja posameznika. Pozornost je treba nameniti individualnemu sodelovanju z ljudmi, upoštevati njihove značilnosti in možnosti, raziskati, katera tveganja lahko predvidimo, in v sodelovanju z njimi narediti načrt z dolgoročnim vplivom na zdravje in se odreči zgolj osredotočanju na trenutno izboljšanje situacije. Socialno delo je pri raziskovanju življenjskega sveta posameznika pozorno tudi na socialne mreže in vire, ki jih lahko črpa iz teh stikov. Če se odzivamo zgolj na stisko človeka, ko se že pojavi, na stisko delujemo le blažilno, to pa ne deluje dolgoročno.

Na mezoravni bi nato morali zagotoviti tiste vire, za katere bi v pogovorih z ljudmi ugotovili, da v skupnosti manjkajo (npr. organizacija takih gibalnih aktivnosti in ob takem času, ki bi ustrezali potrebam ljudi, postavitev klopi ob sprehajalnih površinah, ki bi staremu človeku med gibanjem omogočile počitek). Naše iskanje rešitev ne sme biti omejeno zgolj na storitve in možnosti, ki jih že poznamo, ampak na razvoj tistih, ki jih želijo ali potrebujejo posamezniki. Torej ne izbiramo iz seznama storitev, ampak ustvarjamo nove, pri tem pa je največja prioriteta posameznikova individualnost. Socialno delo lahko pripomore k temu na mezoravni z ozaveščanjem in spodbujanjem raznih društev in organizacij, da omogočajo brezplačne gibalne aktivnosti za spodbujanje zdravega življenjskega sloga. Z vključevanjem v organizirane aktivnosti pa bi si razširili tudi socialno mrežo.

Na makroravni bi preventivne dejavnosti (med njimi tudi gibalne) morali nujno vključiti v sistem in zakonodajo na področju dolgotrajne oskrbe, ki je pri nas še v sprejemanju, saj bi z uvedbo ukrepov, ki bi spodbujali človekovo samostojnost oziroma upočasnjevali proces, ki človeka dela odvisnega, izrazito zmanjšali potrebo po dolgotrajni oskrbi. Takih ukrepov ali programov v dosedanjih predlogih zakona nismo zasledili.

\section{Viri}

Accetto, B. (1987). Starost in staranje: osnove medicinske gerontologije. Ljubljana: Cankarjeva založba.

Berčič, H., \& Sila, B. (2007). Ukvarjanje prebivalstva Slovenije s posameznimi športnimi zvrstmi - 2006. Šport, 3, priloga 17-26.

Bond, J. (2004), Quality life and older people. England: Open University Press.

Cencič, M. (2009). Kako poteka pedagoško raziskovanje: primer kvantitativne empirične neeksperimentalne raziskave. Ljubljana: Zavod Republike Slovenije za šolstvo.

Česen, M. (2006). Reforma zdravstva v Sloveniji. Ljubljana: Zavod za zdravstveno zavarovanje Slovenije.

Dolgotrajna oskrba v Evropski uniji (2008). Luxemburg: Urad za uradne publikacije Evropskih skupnosti. Pridobljeno 15.11. 2018 s http://webcache.googleusercontent.com/search?q=cache:ZQht7DrUEgEJ:ec.europa.eu/social/BlobServlet\%3Fdocld\%3D2781\%26langld\%3Dsl+\&cd=1\&hl=en\&ct=clnk\&gl=si 
Domajnko, B., \& Pahor, M. (2011). Aktivni starejši ljudje o sprejemanju staranja. Pridobljeno 2. 2. 2019 s http://www2.zf.uni-lj.si/ri/publikacije/staranje2011/4.pdf

Dragoš, S. (2000). Socialne mreže in starost. Socialno delo, 39(4/5). Pridobljeno 8. 3. $2020 \mathrm{~s}$ https://www.dlib.si/details/URN:NBN:SI:DOC-DUNY3WLO

Drev, A. (2010). V gibanju tudi v starosti. Ljubljana: Inštitut za varovanje zdravja Republike Slovenije. Pridobljeno 30. 12. 2018 s http://www.nijz.si/sites/www.nijz.si/files/publikacije-datoteke/v_gibanju_tudi_v_starosti.pdf

Filipovič Hrast, M. (2018). Staranje prebivalstva. Zapiski predavanj pri predmetu Skrbstveni režimi in omrežja opor. Ljubljana: Fakulteta za socialno delo.

Filipovič Hrast, M., \& Hlebec, V. (2015). Staranje prebivalstva: oskrba, blaginja in solidarnost. Ljubljana: Fakulteta za družbene vede.

Gabrijelčič Blenkuš, M., \& Stanojević Jerković, O. (ur.) (2010). Prehrana in telesna dejavnost za zdravje pri starejših - pregled stanja. Ljubljana: Inštitut za varovanje zdravja Republike Slovenije. Pridobljeno 3. 1. 2020 s https://www.nijz.si/files/uploaded/prehranaintelesnadejavnoststarejsih_4940.pdf

Gabrovec, B., \& Eržen, I. (2016). Svetovno poročilo o staranju in zdravju. Isis: glasilo Zdravniške zbornice Slovenije, 25(2), 52-53.

Gabrovec, B., \& Jelenc, M. (2015). Skupen evropski pristop v preventivi starostne krhkosti in oslabljenosti v pripravi: joint action on frailty prevention. Isis: glasilo Zdravniške zbornice Slovenije, 24(11), 25-26.

Inštitut Antona Trstenjaka (n.d.). Slovar: socialna mreža. Pridobljeno 3. 8. 2021

s://www.inst-antonatrstenjaka.si/gerontologija/slovar/1433.html

Kahana, E., Lawrence, R. H., Kahana, B., Kercher, K., Wisniewski, A., \& Stoller, E. (2002). Longterm impact of preventive proactivity on quality of life of the old-old. Psychosomatic Medicine, 64, 382-394.

Karpljuk, D., \& Videmšek, M. (2010). Športna rekreacija v tretjem življenjskem obdobju. V M. Tratnik Volasko (ur.), Športna rekreacija danes in jutri: zbornik referatov in razprav, št. 3/2010 (str. 23-31). Ljubljana: Državni svet Republike Slovenije. Pridobljeno 30. 12. 2018 s http://www.ds-rs.si/sites/default/files/dokumenti/zbornik_sportna_rekreacija_danes_in_jutri.pdf

Kavčič, M. (2011). Vsakdanja tveganja starejših ljudi: obravnava koncepta in življenjskih situacij starejših. V S. Mandič, \& J. Mali (ur.), Blaginja pod pritiski demografskih sprememb (str. 161-204). Ljubljana: Fakulteta za družbene vede.

Lesnik, T. (2016). Determinante zdravja. Pridobljeno 30. 12. 2018 s http://obcine.nijz.si/Dokumenti/pdf/2016/Dejavniki\%20tveganja\%20in\%20neenakost\%20v\%20zdravju.pdf

Mali, J. (2008). Od hiralnic do domov za stare ljudi. Ljubljana: Fakulteta za socialno delo.

Mali, J. (2012). Socialno delo s starimi ljudmi in nova socialna zakonodaja. Časopis za kritiko znanosti, 39(250). Pridobljeno 7. 3. 2020 s https://www.dlib.si/details/URN:NBN:SI:DOC-CIGRMBHD

Mali, J. (2013). Socialno delo s starimi ljudmi kot specializacija stroke. Socialno delo, 52(1), 57-67. Pridobljeno 4. 2. 2020 s https://www.revija-socialnodelo.si/mma/Socialno_URN_ NBN_SI_DOC-TWJ8VOFM.pdf/2019032522483030/

Mali, J. (2018a). Koncepti in metode socialnega dela s starimi ljudmi. Zapiski predavanj pri predmetu Dolgotrajna oskrba in socialno delo. Ljubljana: Fakulteta za socialno delo.

Mali, J. (2018b). Socialno delo s starimi ljudmi - spregledano področje socialnega dela. Zapiski predavanj predmeta Dolgotrajna oskrba in socialno delo. Ljubljana: Fakulteta za socialno delo.

Mali, J., \& Leskošek, V. (2015). The impact of austerity measures and disintegrating welfare state on social work with older people in Slovenia. Dialogue in praxis, 4(17), 1/2(28/29), $1-22$.

Mali, J., \& Ovčar, L. (2010). Življenjski svet starejšega kmečkega prebivalstva. Socialno delo, 49(4). Pridobljeno 16. 2. 2020 s https://www.revija-socialnodelo.si/mma/ivljenjski_URN_ NBN_SI_DOC-JH51ENSR.pdf/2019012212491922/ = 
Mali, J., \& Žitek, N. (2016). Narativni pristopi v procesu poučevanja za socialno delo: zgodbe sorodnikov ljudi z demenco kot didaktični pripomoček = Narrative approaches in the process of teaching in social work: stories of relatives of people with dementia as didactic instrument. V K. Aškerc (ur.), Izboljševanje kakovosti poučevanja in učenja v visokošolskem izobraževanju: od teorije $k$ praksi, od prakse $k$ teoriji = Improving the quality of teaching and learning in higher education: from theory to practice, from practice to theory (str. 239-246). Ljubljana: Center RS za mobilnost in evropske programe izobraževanja in usposabljanja.

Nagode, M., Zver, E., Marn, S., Jacović, A., \& Dominkuš, D. (2014). Dolgotrajna oskrba - uporaba mednarodne definicije $v$ Sloveniji. Ljubljana: Urad RS za makroekonomske analize in razvoj. Pridobljeno 13. 11. 2018 s http://www.umar.gov.si/fileadmin/user_upload/publikacije/dz/2014/DZ_02_14p.pdf

Novak, E. (2010). Zdravje in z zdravjem povezan življenjski slog v povezavi z zadovoljstvom z življenjem. Psihološka obzorja, 19(2). Pridobljeno 7. 3. 2020 s http://psiholoska-obzorja. si/arhiv_clanki/2010_2/novak.pdf

Ouwehand, C., De Ridder, D. T. D., \& Bensing, J. M. (2007). A review of successful aging models: proposing proactive coping as an important additional strategy. Clinical Psychology Review, 27(8), 873-884.

Pečjak, V. (1998). Psihologija tretjega življenjskega obdobja. Bled: Samozaložba, in Ljubljana: Znanstveni inštitut Filozofske fakultete.

Petrovec, V., Bizjak, M., Rednak Robič, B., Kopasić, M., \& Kramar, J. (b.d.). Naravoslovje in tehnika 5: e-učbenik za naravoslovje in tehniko v 5. razredu osnovne šole. Pridobljeno 12. 1. 2020 s https://www.iucbeniki.si/nit5/1398/index.html

Povše, M. (2010). Delovanje za zdravo življenje. Pridobljeno 30. 12. 2018 s http://www.mizs. gov.si/fileadmin/mizs.gov.si/pageuploads/podrocje/vs/Gradiva_ESS/Impletum/IMPLETUM_267ORGANIZATOR_Delovanje_Povse.pdf

Rafaelič, A., \& Nagode, M. (2012). Uvajanje dolgotrajne oskrbe. Časopis za kritiko znanosti XXXIX (250). Pridobljeno 19. 11. 2018 s https://www.dlib.si/stream/URN:NBN:SI:DOC-ALR5LMEF/7b5ba784-9897-4c7b-ad02-9436d2823a2f/PDF

Ramovš, J. (2006). Potenciali in potrebe tretje generacije v občini Komenda. Kakovostna starost, 9(3), 19-33.

Selič, P. (1999). Psihologija bolezni našega časa. Ljubljana: Znanstveno in publicistično središče.

Statistični urad Republike Slovenije (b.d.a). Kako gospodinjstva preživijo s svojimi prihodki, glede na dohodek gospodinjstva, Slovenija, letno. Pridobljeno 6. 4. 2020 s https://www. stat.si/StatWeb/News/Index/8616

Statistični urad Republike Slovenije (b.d.b). Prebivalstvo, staro 15 ali več let, po izobrazbi, starosti in spolu, Slovenija, letno. Pridobljeno 6. 4. 2020 s https://pxweb.stat.si/ SiStatDb/pxweb/sl/10_Dem_soc/10_Dem_soc_05_prebivalstvo__20_soc_ekon_preb__01_05G20_izobrazba/05G2002S.px/table/tableViewLayout2/

Tacol, A., \& Goličnik, B. (2014). Duševno zdravje: pozitivna samopodoba in stres. V B. Zupančič Tisovec, J. Janc, D. Kunšek, K. Rupnik, E. Mesarič, G. Toth, Z. Verban Buzeti, N. Rožman, M. Kašnik, M. Rebula, N. Pogorevc, B. Božank, A. Horvat, M. Učakar, F. Hribernik, P. Pažek, A. Magajna, L. Krampač, A. Tacol, B. Goličnik, I. Markočič, T. Torkar, \& A. Hafner, Za boljše zdravje otrok in mladostnikov: priročnik za izvajalce vzgoje za zdravje v okviru primarnega zdravstvenega varstva (str. 99-110). Ljubljana: Nacionalni inštitut za javno zdravje. Pridobljeno 26. 12. 2018 s https://www.dlib.si/details/URN:NBN:SI:DOC-NEMNVOPV

Toth, M. (2009). Dolgotrajna oskrba - nova veja socialne varnosti. Delo in varnost, LIV(2). Pridobljeno 13. 11. 2018 s https://www.dlib.si/stream/URN:NBN:SI:DOC-RCZOL6LW/ dd20adc3-5def-41a6-bef1-7d0dac18810f/PDF

Urad za makroekonomske analize in razvoj (b.d.). Strategija dolgožive družbe. Pridobljeno

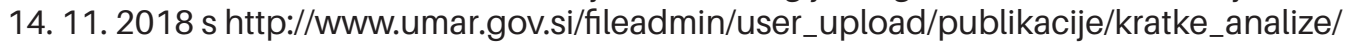
Strategija_dolgozive_druzbe/UMAR_SDD.pdf

Vilčnik, V. (b.d.). Prepoznajmo in olajšajmo najpogostejše težave starejših. Pridobljeno 27. 12. 2018 s http://www.abczdravja.si/index.php/8-novice/55-prepoznajmo-in-olajsajmo-najpogostejse-tezave-starejsih 
Voljč, B. (2017). Dolgotrajna oskrba na političnem izpitu. Delo, 5. 12., pridobljeno 13. 11. $2018 \mathrm{~s}$ https://www.delo.si/mnenja/gostujoce-pero/dolgotrajna-oskrba-na-politicnem-izpitu.html

World Health Organization (b.d.). What is the WHO definition of health? Pridobljeno 31. 12. 2018 s https://www.who.int/suggestions/faq/en/

World Health Organization (2018). Physical activity. Pridobljeno 20. 1. 2020 s https://www. who.int/news-room/fact-sheets/detail/physical-activity

Zdrav življenjski slog - trajnostni razvoj (b.d.). Pridobljeno 30. 12. 2018 s http://www.cpi.si/ files/cpi/userfiles/trajnostnirazvoj/07_zdrav_zivljenjski_slog.pdf

Zveza društev upokojencev Slovenije (2013). Zdravje starejših v EU. Pridobljeno 1. 1. $2019 \mathrm{~s}$ http://www.zdus-zveza.si/zdravje-starejsih-v-eu 